\title{
CURRENT ISSUES OF CONSTITUTIONAL DAMAGES LITIGATION: A CONTEXTUAL ANALYSIS OF RECENT COMMONWEALTH DECISIONS
}

\author{
Chuks Okpaluba \\ LLB LLM PhD \\ Adjunct Professor of Law \\ Nelson Mandela School of Law \\ University of Fort Hare
}

\section{SUMMARY}

The Privy Council judgments in James v Attorney General [2010] UKPC 23 and Graham v Police Service Commission [2011] UKPC 46 have advanced the constitutional damages jurisprudence not only in Trinidad and Tobago but also the Commonwealth since Attorney General v Ramanoop [2005] 2 WLR 1324 (PC). In their recent decision in Seepersad v Attorney General [2012] UKPC 4, their Lordships answered two crucial questions hitherto not contested in South Africa or any other Commonwealth court relating to a right to a constitutional remedy and a constitutional right to damages. They held that constitutional damages were the appropriate relief as against those cases where constitutional relief were sought in non-constitutional circumstances. The Supreme Court of Canada has equally contributed to the subject by holding in Canada (Attorney General) v TeleZone Inc [2010] 3 SCR 585 (SCC) that a claimant for Charter damages does not have to obtain judicial review before seeking such relief. This article argues that, while TeleZone has restored the citizen's right of access to the courts by removing unnecessary procedural obstacles to Charter damages claim, the Privy Council has, through Seepersad, once more laid down principles which South African and other Commonwealth courts may freely refer to if and when similar issues arise in constitutional damages litigation in their jurisdictions.

\section{$1 \quad$ INTRODUCTION}

Since the Privy Council enunciated the principle that constitutional damages were recoverable as a remedy for breach of a constitutionally entrenched right in Maharaj $v$ Attorney General of Trinidad and Tobago (2), ${ }^{1}$ litigants in Trinidad and Tobago in particular, and the Commonwealth Caribbean in general, have sought that relief in varied, if bewildering circumstances. In the process, both the Privy Council and the litigants have contributed enormously to the development of the constitutional damages jurisprudence in the

[1979] AC 385 (PC). 
Commonwealth. For instance, through the litigation in James $v$ Attorney General of Trinidad and Tobago, ${ }^{2}$ the Privy Council articulated the principle that a claimant for breach of a fundamental right should prove damage not only for the purposes of quantification but also for the determination of the appropriateness of damages as a relief in the case. It was held further that the award of damages where violation of a constitutional right has occurred is not automatic. In effect, damages do not necessarily flow from the facts of breach of a right. ${ }^{3}$ Otherwise, the discretion invested in the court by section 14 of the Constitution Trinidad and Tobago 1976 would be undermined. ${ }^{4}$

Shortly before James, the Privy Council was confronted in a line of cases with what award had to be made where plaintiffs successfully proved that damages were the appropriate relief for the constitutional violations in question. Consequently, their Lordships advanced the Maharaj (2) formulation by making severally: an "additional award", a "substantial award" 6 and "exemplary damages" as forms of vindicatory damages awarded where fundamental rights breaches have occurred, given the nature of the right and the damage inflicted. ${ }^{8}$ In other instances, the question turned on whether dismissed public officers were entitled to constitutional damages, and if so, what factors should be taken into account where their appointments were terminated contrary to the relevant constitutional procedure.

Subsequently, their Lordships rejected the appellant's claim for an additional award by way of vindicatory damages in Graham $v$ Police Service Commission of Trinidad and Tobago, ${ }^{10}$ given the nature of the claim. While such award was made in Ramanoop where various forms of personal liberty infringements were involved, the violation in Graham was a failure to accord the appellant a right to be heard occasioning a breach of his right to equality of treatment guaranteed by section $4(\mathrm{~d})$ of the Trinidad and Tobago Constitution. It was a case of pure administrative bungling ${ }^{11}$ in handling his

[2010] UKPC 23 (29 July 2010) par 40-42.

Contra Ashby v White (1703) 2 Raym 938 953; and see Okpaluba "Constitutional Damages, Proof of Damage and the Privy Council" 2011 74(4) THRHR 567576 and 582 respectively.

Per Lord Kerr, James $v$ Attorney General supra par 36.

Attorney General v Ramanoop [2005] 2 WLR 1324 (PC) par 19.

Merson v Cartwright [2005] UKPC 38 (PC) (13 October 2005) par 19.

Takitola v Attorney General [2009] UKPC 12 (Bahamas) (18 March 2009) par 15.

8 See generally, Okpaluba "Vindicatory Approach to the Award of Constitutional and Public Law Damages: Contemporary Commonwealth Developments" 2012 65(2) CILSA 127.

9 See eg. Inniss v Attorney General of Saint Christopher and Nevis [2008] UKPC 42 (PC); Fraser v Judicial and Legal Services Commission [2008] UKPC 25 (PC) par 22; and discussed in Okpaluba "Constitutional Damages, Procedural Due Process and the Maharaj Legacy (Part II)" 2012 27(1) SAPL 136.

10 [2011] UKPC 46 (20 December 2011) par 17.

11 Actions for damages based on administrative decision-making error(s) have failed in many cases, eg, South African Post Office v De Lacy 2009 (5) SA 255 (SCA); Steenkamp NO v Provincial Tender Board, Eastern Cape 2006 (3) SA 151 (SCA), 2007 (3) SA 121 (CC); Telematrix (Pty) Ltd t/a Matrix Vehicle Tracking v Advertising Standards Authority of South Africa 2006 (1) SA 461 (SCA); Premier, Western Cape v Fair Cape Property Developers (Pty) Ltd 2003 (6) SA 13 (SCA); Olitzki Property Holdings v State Tender Board 2001 (3) SA 1247 (SCA); D v East Berkshire Community Health NHS Trust [2005] 2 WLR 993 (HL); Sullivan v Moody (2001) 207 CLR 562 (HCA); State of New South Wales v Paige [2002] NSWCA 235; Te Mata Properties Ltd v Hastings District Council [2009] 1 NZLR 460 (CA); and Brown v Attorney General [2003] 3 NZLR 335. 
promotion. There was no evidence of bad faith, deliberate wrongdoing, highhandedness or oppressive conduct by state agents. Rather, the respondent backdated his seniority twice and indicated that consideration would be given to his "relative seniority when next promotions to the office of Assistant Commissioner of Police are made". ${ }^{12}$ Like in James, the appellant provided no particulars of damage suffered and led no evidence of loss. Thus the available information bearing on his pecuniary loss was meagre and incomplete. There was, therefore, no basis upon which to make an additional award or to order a separate assessment of damages before a Master. ${ }^{13} \mathrm{Sir}$ John Laws held that Lord Scott's aphorism that the nature of constitutional damages was always vindicatory ${ }^{14}$ did not imply that a distinct vindicatory award should have been made in every constitutional violation. It merely serves to indicate the overall purpose of any award of damages in constitutional cases. ${ }^{15}$

Now, the most recent contribution of the Privy Council on constitutional damages is Seepersad $v$ Attorney General, ${ }^{16}$ where the question raised was closer to those earlier cases which concerned whether constitutional relief was the proper way to approach the court, ${ }^{17}$ than the more recent cases on vindicatory damages. Indeed, their Lordships declined the invitation to give guidance on the assessment of damages in Seepersad, where persons were sentenced under section 79 of the Children Act 1925. It was not for their Lordships to formulate such guidelines but the Court of Appeal of Trinidad and Tobago having had regard to its knowledge of the local conditions and the needs of the local judiciary. ${ }^{18}$ That process of elimination therefore left two issues for determination. First, was there a right to a constitutional remedy? ${ }^{19}$ This turned out to be another way of inquiring as to whether a constitutional relief was appropriate in the circumstances of the case. Second, was there a constitutional right to damages? $?^{20}$ In effect, were the appellants entitled to damages? The pronouncements of Lord Hope on these issues were distinct contributions to the development of constitutional damages debate in the Commonwealth and are, therefore, the focus of this article. The discussion begins with a brief reference to the important issues relating to constitutional damages in other Commonwealth jurisdictions so as to capture the stage of development of the South African constitutional damages litigation. Because of its contemporaneous relevance to the constitutional damages jurisprudence, this article sets out the background to Seepersad followed by a discussion of the judgment of the Privy Council on the two crucial issues already mentioned. An analogy is drawn to the wave of attacks in Canada

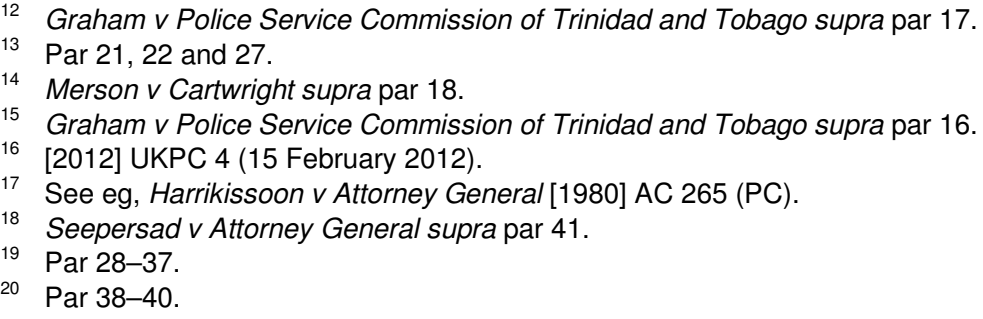


where it is contended that claims for Charter damages cannot proceed without the claimant first obtaining judicial review of the alleged wrongful act. ${ }^{21}$

\section{RECENT DEVELOPMENTS IN NEW ZEALAND, IRELAND AND SOUTH AFRICA}

In addition to the development in Canada discussed later in this article, there are developments in New Zealand and South Africa which must also be noted. Although a common thread runs through the approach of these two jurisdictions within the context of this discussion, the approaches of these two jurisprudences vis-à-vis constitutional damages otherwise differ. For instance, New Zealand is one jurisdiction in the Commonwealth where the Maharaj (2) formulation in respect of breaches by the judiciary of the rights in the Bill of Rights Act $1990^{22}$ was embraced in its entirety. On the other hand, it is safe to say that the Constitutional Court judgment in Fose $v$ Minister of Safety and Security $^{23}$ did not actually encourage resort to constitutional damages as appropriate relief for breach of fundamental rights in the South African Constitution. While it subtly left the matter to the litigant, it, however, showed preference to the delictual approach. Indeed, Ackerman $\mathrm{J}$ held that the South African common law of delict was flexible and under section 35(3) of the interim [1993] Constitution should be developed by the courts with "due regard to the spirit, purport and object" of Chapter 3. In many cases the common law will be broad enough to provide all the relief that would be "appropriate" for breach of constitutional rights"24 The other reason is the actual development of the common law along the guidelines set down in Carmichele $v$ Minister of Safety and Security. ${ }^{25}$ A combination of Fose and Carmichele, therefore, effectively opened the door for plaintiffs to seek damages for breaches of their fundamental rights through constitutional delict actions. $^{26}$

\section{$21 \quad$ New Zealand}

In Chapman $v$ Attorney General, ${ }^{27}$ the Supreme Court of New Zealand revisited the Maharaj (2) formulation in respect of breaches by the judiciary of the rights in the Bill of Rights Act 1990. The question was whether the wellestablished principle that damages were recoverable directly against the state

21 See eg, Canada (Attorney General) v TeleZone Inc [2010] 3 SCR 585 (SCC); and Canada (Attorney General) v McArthur [2010] 3 SCR 626 (SCC).

22 New Zealand does not have a written constitution, but her Court of Appeal have approached the interpretation of her Bill of Rights Act 1990 as if it were a constitutional instrument. In Simpson v Attorney General [Baigent's case] [1994] 3 NZLR 667 (CA), by embracing the Maharaj 2 constitutional damages concept - an approach affirmed and consolidated by the Supreme Court in Taunoa v Attorney-General [2008] 1 NZLR 429.

231997 (3) SA 786 (CC).

${ }^{24}$ Par 58(b). See further, Okpaluba "The Development of Charter Damages in Canada: The Guidelines from the Supreme Court" forthcoming 2012 23(1) Stell LR 55 par 2.3.

252001 (4) SA 938 (CC).

26 See eg, Zealand v Minister of Justice and Constitutional Development 2008 (4) SA 458 (CC); Lee v Minister of Correctional Services 2013 (1) SA 144 (CC); and Alves v LOM Business Solutions (Pty) Ltd 2012 (1) SA 399 (GSJ).

27 [2011] NZSC 110 (16 September 2011). 
for breaches of rights enshrined in that Act extends to a breach of the rules of natural justice by a judge in adjudication or, whether there was a "judicial carve-out"? ${ }^{28}$ Alternatively, is the liability of the state in this instance an exception to the principle that judges are immune from liability acting in their judicial capacity? Alternatively, is the concept of constitutional damages inconsistent with that common-law immunity principle? Further, considering that the state liability for constitutional damages within the Maharaj (2) formulation is a separate cause of action distinct from the common-law tort, does it encompass judicial act or omission, or, is Maharaj (2) bad law? It may be recalled that one of the concerns expressed by Lord Hailsham in his dissent in Maharaj (2) ${ }^{29}$ and Gault $J$ in Baigent's case ${ }^{30}$ was the operation of the principle of judicial immunity and state immunity under the Crown Proceedings Act. The courts in New Zealand have, at several occasions in the last two decades, expressed conflicting opinions on the application of the Maharaj (2) principle to judicial conduct. ${ }^{31}$ The Supreme Court has now had the opportunity of deliberating on the issue in Chapman.

The diverging conclusions arrived at by the five Judges of the Supreme Court in Chapman illustrate the tension between direct state liability for judicial error as in Maharaj (2) and the common law of judicial immunity, notwithstanding Lord Diplock's explanation that the award was not designed to subvert the concept of judicial immunity. Representing the majority, McGrath and William Young $J J$ (Gault $J$ concurring) held that the desirability of finality in litigation, the importance of judicial independence and the attendant public confidence, the extensive protection against judicial breach afforded by the justice system and, in particular, the current appellate process, were some of the public policy reasons which supported personal judicial immunity. ${ }^{32}$ They also justified confining the scope of Crown liability for governmental breaches of the Bill of Rights Act to actions of the executive branch. Such liability should not be extended to cover breaches resulting from the actions of the judicial branch. This was not an extension of judicial immunity itself; but recognition that the public-law cause of action against the Crown held in Baigent's case to be implicit in the Bill of Rights Act, would not appropriately be extended to cover breaches by the judicial branch. ${ }^{33}$ Accordingly, the court did not have jurisdiction to hear and determine the respondent's claim for public law compensation, for alleged breaches by the

28 Per Elias CJ, Chapman v Attorney General supra par 53.

29 Maharaj v Attorney General of Trinidad and Tobago (2) supra 409D-G.

30 Baigent's case 714-715; and AUW Rights Centre Inc v Attorney General [1994] 3 NZLR 720 (CA) 729-730.

31 Based on Baigent's case, the courts in New Zealand have awarded damages against the state for judicial conduct in AUW Rights Centre Inc v Attorney General supra 729-730; Harvey v Derrick [1995] 1 NZLR 314 (CA); Martin v Tauranga District Court [1995] 2 NZLR 419 (CA); Rawlinson v Rice [1997] 2 NZLR 651 (CA); and Upton v Green (No 2) (1998) 5 HRNZ 54 (CA). That such was the law in New Zealand was assumed in Lai $v$ Chamberlains [2007] 2 NZLR 7 (NZSC) par 66 and 74; and $R v$ Williams [2009] 2 NZLR 750 (NZSC) par 18. It was William Young $\mathrm{J}$ who, in his extensive dictum in Brown $v$ Attorney General [2005] 2 NZLR 405 (CA) par 127-132, expressed the view that Maharaj (2) had been effectively overruled and that Baigent's case had to be read in the narrow compass in which it was decided. The problem was thus directly deliberated upon in McKean v Attorney General [2009] NZCA 553; and Attorney General v Chapman [2010] NZLR 317 (NZCA).

32 Attorney General $v$ Chapman supra par 183-186, 189 and 192-194.

33 Par 204. 
judiciary of sections 25 and 27 of the Bill of Rights Act, occurring in the course of determining his criminal legal aid application and his appeal against conviction. ${ }^{34}$

\section{Ireland}

Like the majority in Chapman, the High Court in Ireland considered whether constitutional damages were the proper relief in circumstances similar to that in Maharaj (2) and refused to apply them. Maharaj (2) was cited in Kemmy $v$ Ireland ${ }^{35}$ but it was distinguished on the ground that it could not displace the common-law judicial immunity.

\section{South Africa}

The facts of Claassen v Minister of Justice and Constitutional Development ${ }^{36}$ were closely similar to those of Maharaj (2) and Kemmy in that there was a deprivation of liberty through judicial error, but Maharaj (2) was not cited, distinguished or referred to in Claassen. This is partly due to the fact that constitutional damages in South Africa have yielded to the domineering influence of what can loosely be described as constitutional delict. ${ }^{37}$ Again, this development is as a result of the emphasis laid by the Constitutional Court on the capacity of the common law to accommodate constitutional damages claims through the law of delict. ${ }^{38}$ Claassen, like Chapman and Kemmy, was decided on the common-law judicial immunity basis without having to confront the Maharaj (2) dilemma. ${ }^{39}$ It was held that, although the

${ }^{34}$ Par 209. Elias CJ dissenting (Anderson J concurring) par 8 and 58-60 held that it would be contrary to the scheme and purpose of the New Zealand Bill of Rights Act 1990 if those deprived of rights through judicial action were denied the opportunity to obtain damages from the state, where an award of damages was necessary to provide effective remedy. Under s 3(a) of the Act, all branches of the government, including the judicial branch, were bound to observe and protect the rights affirmed. A gap in remedy for judicial breach was contrary to the obligation of the state to provide effective remedy in domestic law. Excluding remedy for judicial breaches would leave a large remedial hole because many of the rights affirmed in the Act were afforded principally within judicial process through discharge of judicial function. They included in particular the "[m]inimum standards of criminal procedure" contained in s 25 and the "[r]ight to justice" contained in s 27 . If breaches through judicial act were irremediable, such rights were undermined. The immunity of the state herein suggested was in principle inconsistent with the rule of law and should not be extended in the interests of the administration of justice. Essentially, because direct State liability for judicial breach of rights did not undermine the purposes for which personal judicial immunity was imposed. Further, state liability for public law damages was no more inconsistent with judicial immunity than it was with the statutory immunities of police officers in Baigent's case. Lastly, effective vindication of the Bill of Rights Act required the availability of a direct remedy in damages so that any policy supporting an exception had to be overwhelming to justify conferring immunity from the general remedial response available to the courts in vindication of breaches of the Bill of Rights Act.

35 [2009] IEHC 178 (25 February 2009). Contra, McFarlane v Ireland [2010] ECHR 1272 (10 September 2010).

362010 (6) SA 399 (WCC).

37 Cf the American equivalent of "constitutional torts" - Rosenthal "A Theory of Governmental Damages Liability: Torts, Constitutional Torts and Takings" 20079 University of Pennsylvania Journal of Constitutional Law 797.

38 Fose $v$ Minister of Safety and Security supra.

39 See also Telematrix (Pty) Ltd t/a Matrix Vehicle Tracking $v$ Advertising Standards Authority of South Africa supra, where the claim was for financial loss arising from incorrect adjudication 
magistrate acted negligently in that his conduct fell below that of a reasonable person in his position, but absent mala fides or malice, he was immune from civil liability having acted in his judicial capacity. The absence of a discussion of Maharaj (2) formulation meant that the opportunity to consider the constitutional damages as an alternative cause of action in such a case which actually translated to holding the state directly liable for such judicial error was lost. And, with it, the opportunity to balance the heavy emphasis placed on the protection of the entrenched rights and judicial accountability as founding values of the South African Constitution ${ }^{40}$ with the common-law doctrine of judicial immunity.

\section{BACKGROUND TO SEEPERSAD}

The appellants were convicted for murder and sentenced on 21 July 1986. They were under 18 and so were not subjected to the mandatory death penalty upon conviction for murder had they been of full age. They were sentenced under section 79 of the Children Act 1925 to be detained at the state's pleasure. Under section 81 of that Act the state had discretion to discharge a detainee on licence at any time. But no provision was made by the statute for any period to be laid down by the court which the detainee had to serve before being considered for release by the state or for the periodic review of the detention. In the case of the first appellant the warrant of commitment to prison stated that it was the court's wish that he remained in prison for as long as possible. The appellants did not appeal against their sentences nor object to their terms or the way in which the sentences were being administered until 2003. They then brought constitutional proceedings challenging the sentences and the manner of their execution on two grounds. They contended that the sentences offended against the constitutional principle of separation of powers. This was because section 79 provided that they were to be detained at the pleasure of the state, and not for a term to be determined by the High Court. This argument was premised on both the common law and sections 4 and 5 of the Constitution of Trinidad and Tobago with which they argued sections 79 and 81 of the Act were incompatible. Secondly, the manner of the execution of the sentences was in breach of sections 4 and 5 of the Constitution because, contrary to their nature and character, they were not being reviewed periodically by the court. ${ }^{41}$

When the appellants first raised these objections they were still in custody, where they had been since their arrest in 1981. Their main aim at this stage was to secure their release on a date to be determined by the court and not by the state. They also sought constitutional relief by way of damages. They were successful in securing their release from custody pursuant to the orders of the High Court of 24 and 26 June 2006. In order for them to succeed in their action for damages, they first had to establish that the manner of the execution of their sentences was a breach of their rights under sections 4(a)

rendered by a tribunal unlike in Claassen where the injury was a deprivation of personal liberty.

40 See Okpaluba "Constitutional and Delictual Damages for Judicial Acts and Omissions: A Review of Claassen and Recent Common Law Decisions" 2011/2012 19(2) Les LJ 1.

${ }^{41}$ Seepersad $v$ Attorney General supra par 3. 
and (b) and 5(2)(h) of the Constitution. They had to meet the Attorney General's argument that, unless and until the relevant sections of the Children's Act were modified to meet the objection that they offended against the doctrine of separation of powers, they were detained at the pleasure of the State. This, according to the Attorney General, was of the very essence of the sentence provided for by the statute regardless of its lawfulness. It was thus submitted that there was no place for their periodic review by the court until the sections were modified. ${ }^{42}$

Section 79 of the Act which abolished the death sentence in the case of persons under the age of eighteen years was inserted by the Criminal Law Act 6 of 1953. At the time when the Constitution came into force in 1976, sections 79 and 81 were both existing law. It follows that they were preserved from challenge by section 6(1)(a) of the Constitution hence could not be invalidated by anything in sections 4 and 5 of the Constitution. ${ }^{43}$ Accordingly, the Court of Appeal rejected the appellants' complaint that they had been deprived of their constitutional rights because there had been no effective review of their sentences of detention while they remained in custody in which the trial judge had held that section 6(1) precluded them from mounting a challenge based on sections 4 and 5 of the Constitution. The first issue before the Privy Council, therefore, was whether the appellants' claim that their rights under sections 4(a) and (b) and 5(2)(h) were breached because of the way their sentences of detention were executed was precluded by section 6(1) of the Constitution. ${ }^{44}$

For the appellants, it was submitted that the Court of Appeal misconstrued their complaint as it was based, not on a challenge to the statute itself, but on the state's failure to execute the indeterminate sentences in a manner which accorded with their fundamental nature which required periodic review. The appellants were not seeking to invalidate any law at all. Their challenge related to what was done under the authority of that law. This was not precluded by section 6(1), as it did not extend to acts or omissions done under the authority of the law which contravened any of the provisions in sections 4 and 5 . Furthermore, there was a pre-existing common-law right to a review of the appellants' detention which was protected by sections 4(a) and (b) and 5(2)(h) of the Constitution. There had therefore been a breach of the appellants' rights under those provisions which entitled them to a remedy under section $14 .^{45}$

The state argued, inter alia, that the remedy of judicial review could have been asserted from the inception of the sentences in 1986. Alternatively, the lawfulness of the sentences could have been challenged by an appeal. The fact that these remedies were available was sufficient to satisfy the constitutional right to due process. ${ }^{46}$ The second issue was directed to the appellants' claim for damages which, the Court of Appeal held, did not arise as there was no breach of the appellants' constitutional rights. In any case, it would become a live issue if the appellants succeeded on the first issue. In

42 Par 4.

43 Matthew $v$ State of Trinidad and Tobago [2005] 1 AC 433 par 14.

44 Seepersad v Attorney General supra par 23 and 24.

45 Par 25.

46 Seepersad v Attorney General supra par 26. 
that regard, two questions arise. The first is whether the order of the High Court on 13 January 2006; the subsequent review of the appellants' detention; their release on 26 July 2006 and the declaratory relief that was provided by the order of the Court of Appeal of 14 December 2009 provided the appellants with adequate redress in all the circumstances. Hence it would not be appropriate to make an award of damages. The second is: if the appellants were not to be limited to the reliefs already given, then the question of damages remained open. ${ }^{47}$

\section{THE PRIVY COUNCIL JUDGMENT AND DIS- CUSSION OF THE ISSUES IN SEEPERSAD}

\section{Is there a right to a constitutional remedy?}

The substance of the argument in this context is that constitutional remedy was not open to the appellants because they could have availed themselves of the remedy of judicial review which would have satisfied the right of due process. In other words, if the sentence of detention at the state's pleasure was to be regarded as an unlawful sentence, the appellants could have taken up that point by way of appeal against the sentence at the outset. The Privy Council rejected the argument relating to appeal when the sentence was imposed as "wholly unrealistic" bearing in mind that the profound changes in the law that opened up the possibility of such a challenge happened long after the time when an appeal could have been brought. ${ }^{48}$ On the other hand, the first limb of the argument has two angles. The first is the availability of alternative judicial remedy, while the second is the fallacy of seeking constitutional relief for purely administrative breach disguised as fundamental right.

\section{Availability of judicial review}

A well-established principle of constitutional adjudication applicable to claims for constitutional- and public-law damages ${ }^{49}$ is that parties must seek available alternative modes of obtaining relief under other branches of the law without resorting to the constitutional motion. ${ }^{50}$ In public law, damages are a remedy of last resort awarded only in exceptional cases. ${ }^{51}$ Thus, a court must

47 Par 27.

48 Par 33

49 Cf s 24(2) of the Constitution of Barbados 1971; and see Smithfield Foods Ltd v Attorney General of Barbados [1992] 1 WLR 197 (PC).

50 See eg, Ex parte Minister of Safety \& Security: In Re S v Walters 2002 (4) SA 613 (CC) par 64-67; Minister of Education v Doreen Harris 2001 (11) BCLR 1157 (CC) 1165-1166 par 19; National Coalition for Gay \& Lesbian Equality v Minister of Home Affairs 2000 (2) SA 1; (1) BCLR 39 (CC) par 21; Motsepe $v$ Commissioner for Inland Revenue 1997 (2) SA 898 (CC) 908D-E par 21; S v Mhlungu 1995 (3) SA 867 (CC) par 59; Zanti v Council of State, Ciskei 1995 (4) SA 615 (CC) 617-619; and Okpaluba "Justiciability and Constitutional Interpretation in the Commonwealth: The Problem of Definition (1)" 200366 THRHR 424446.

51 This is supported by $s$ 8(1)(c)(ii)(bb), Promotion of Administrative Justice Act of 2000 (RSA). The English Court of Appeal held in $R v$ Epping \& Harlow General Commissioners, ex parte Goldstraw [1983] 3 All ER 257 (CA) that, save in the most exceptionable circumstances, the judicial review jurisdiction will not be exercised where other remedies were available and were 
consider whether any other remedy would be more appropriate. ${ }^{52}$ This clearly conforms to the central theme of the judgments of the Privy Council in Harrikissoon v Attorney General ${ }^{53}$ Hinds v Attorney General of Barbados ${ }^{54}$ and Jaroo $v$ Attorney Genera ${ }^{55}$ to the effect that, where there is available alternative modes of obtaining relief under another branch of the law, it is an abuse of process to resort to the constitutional motion. ${ }^{56}$ This principle was affirmed by Lord Nicholls when he held in Attorney General of Trinidad and Tobago $v$ Ramanoop ${ }^{57}$ that where there was a parallel remedy constitutional relief should not be sought unless the circumstances of the complaint included some feature which would have made it appropriate to take such a course.

In a number of subsequent cases since Jaroo, complainants have continued to resort to the constitutional process contrary to the optimism expressed by Hamel-Smith JA that Jaroo brought the rampant use of the constitutional motion to a "sudden and welcome halt" ${ }^{58}$ For instance, the appellant in Johnatty $v$ Attorney Genera ${ }^{p 9}$ approached the court by way of enforcement of his fundamental right in what was purely an employment matter. The Privy Council held that the appellant's constitutional motion against the decision of the employer to stop payment of his salary was an abuse of process. This was an affirmation of the trial court's ruling that the appellant had an alternative remedy in the form of an action for damages against his employer for breach of contract and the Court of Appeal's decision that he had a parallel remedy in proceedings for judicial review. It was held that it would have been open to the appellant to seek a private-law remedy against his employer for non-payment of his salary. It was also open to him to seek judicial review, as demonstrated by the fact that his constitutional motion was based on the same facts as those proceedings for judicial review. This judgment is eminently supported by the foregoing line of cases where the availability of alternative remedy proved fatal to the appellants' constitutional cause of action.

Again, it was held in Durity $v$ Attorney Genera ${ }^{\rho 0}$ that the Magistrate was not deprived of his protection of the law because the Judicial and Legal Services Commission took the initial step to set up an investigation into whether he exceeded his jurisdiction in relation to a bail controversy since it was open to

not used. See also $R v$ Chief Constable of the Merseyside Police, ex parte Calveley [1986] 2 WLR 144 (CA); and $R v$ Secretary for the Home Department, ex parte Swati [1986] 1 WLR 477 (CA).

52 Judicial review was held to be adequate remedy in Yuen Kun-Yeu v Attorney General of Hong Kong [1987] 2 All ER 705 (HL) whereas the availability of the tort of misfeasance in public office was one of the reasons that justified the non-actionability of a claim in negligence for an act of maladministration in Calveley $v$ Chief Constable of the Merseyside Police [1989] AC $12281238(\mathrm{HL})$.

53 [1980] AC 265 (PC) 268.

54 [2002] 1 AC 854 (PC).

55 [2002] 1 AC 871 (PC) par 39.

56 See also Attorney General of Jamaica v Dunhai Williams [1997] UKPC 22 (PC) par 19 and 45.

57 [2006] 1 AC 328 (PC) par 25.

58 George $v$ Attorney General of Trinidad and Tobago (Unreported) (8 April 2003).

59 [2008] UKPC 55 (PC) par 20 and 21.

60 [2008] UKPC 59 (PC). 
him to promptly challenge the legality of the decision by means of judicial review. Thus, taken on its own the complaint was not one that stood up to examination as an infringement of the appellant's constitutional rights. In any event, as a remedy by way of judicial review was available from the outset, a constitutional motion was never the right way of invoking judicial control of the Commission's decision to suspend him. The choice of remedy is not simply a matter for the individual to decide upon as and when he pleases. Therefore, the decision to suspend the appellant was not a proper subject for relief by way of a constitutional motion under section 14 of the Constitution of Trinidad and Tobago. ${ }^{61}$

On the submission that the appellant should have challenged the delay in judicial review proceeding, their Lordships came to a different conclusion. It was held that the responsibility for appointing an investigating officer forthwith lay entirely with the Commission, not for the appellant to take the initiative. It was for the Commission to adhere to the standard laid down in its Regulations. It was, however, doubtful whether judicial review could have afforded adequate relief for a past and irreversible event such as the alleged unlawful continuation of a suspension. ${ }^{62}$ On the other hand, their Lordships held that not only was there a breach of the constitutional right to due process, the appellant was entitled to constitutional relief. As Lord Hope explained:

"The Harrikissoon principle on which Mr Dingemans relies to defeat the
appellant's constitutional motion is based on the assumption that there was
another procedure for obtaining a sufficient judicial remedy for the unlawful
administrative action of which the person complains. If there was, he ought to
have invoked it. For the reasons just given, however, that cannot be said to be
the situation in this case. The appellant is not to be criticised for not resorting to
the uncertain procedure of judicial review as a means of enforcing the
Commission's obligation to deal with his case promptly. It was for the
Commission to ensure that it adhered to that standard, not for the appellant to
prompt it to do so."

It is important to bear in mind that the overriding phrase in the court's consideration of what remedy to grant an aggrieved person in the event of breach of a fundamental right is the relief it "considers appropriate" as provided for in the Caribbean Constitutions, ${ }^{64}$ or "appropriate relief" and equitable" as it appears in the South African Constitution. ${ }^{66}$ In construing "appropriate relief" in the South African Constitution, the Constitutional Court has emphasized that it had to not only be the most effective cure for the breach, it had to also be the relief which "is required to protect and enforce the Constitution". ${ }^{67}$ It should, when measured alongside other judicial remedies, ${ }^{68}$

61 Par 28.

62 Par 31.

63 Par 32.

64 See eg, s 14(2) of the Constitution of Trinidad and Tobago 1976; s 96(3) of the Constitution of St Christopher and Nevis 1983; and s 105(3) of the Constitution of St Lucia 1978.

$65 \mathrm{~S} 38$ of the Constitution of the Republic of South Africa, 1996.

66 S 172(1)(b) of the Constitution of the Republic of South Africa, 1996; and s 8(1) and (2) of the Promotion of Administrative Justice Act 3 of 2000.

67 Per Ackermann J, Fose v Minister of Safety and Security supra par 19. 
satisfy the test as that "specially fitted or suitable" by the extent to which it would vindicate the Constitution and act as a deterrence against further violations of the rights guaranteed by the Constitution. ${ }^{69}$ In addition to effectiveness and suitability, "appropriate relief" must be that which meets the demands of "fairness and justice" "70 when the interests of those who might be affected by the court's order are balanced on the scale of justice. ${ }^{71}$

It is in line with this reasoning that Lord Hope held in Seepersad that the objection that the sentences were not being reviewed could have availed themselves of judicial review "has, perhaps, more to commend it". ${ }^{72}$ Yet, having regard to the facts, their Lordships were not persuaded that availability of the remedy of judicial review rendered the proceedings an abuse of process or otherwise unsustainable. Lord Hope cited Attorney General v McLeod, ${ }^{73}$ where Lord Diplock held that the existence of a right of access to the courts of justice to declare that an Act of Parliament was invalid was sufficient to preserve the constitutional right to the protection of the law to which the individual was entitled under section $4(\mathrm{~b})$ of the Constitution of Trinidad and Tobago. ${ }^{74}$

\section{The fallacy of fleshing out fundamental rights from administrative breaches}

In propounding the principle essential to the enforcement of fundamental rights in Maharaj (2), Lord Diplock was at pains to explain the novel constitutional jurisprudence he was enunciating bearing in mind that the cause of action arose from an error of a judge in adjudication. Pertinent to this discussion and underlining the resort to the constitutional motion, Lord Diplock's had said that:

"The fundamental human right is not to a legal system that is infallible but to one that is fair. It is only errors in procedure that are capable of constituting infringements of the rights protected by section $1(\mathrm{a}) ;{ }^{75}$ and no mere irregularity in procedure is enough, even though it goes to jurisdiction; the error must amount to a failure to observe one of the fundamental rules of natural justice. Their Lordships do not believe that this can be anything but a very rare event.

By reference to the error being "a very rare event", Lord Diplock must have meant that the redress which the appellant obtained in that case was indeed

68 See Okpaluba "Of Forging New Tools" and 'Shaping Innovative Remedies': Unconstitutionality of Legislation Infringing Fundamental Rights Arising from Legislative Omissions in the New South Africa" 200112 Stellenbosch LR 461 464-469.

69 Per Kriegler J, Fose v Minister of Safety and Security supra par 97.

70 Per Ngcobo J, Hoffman v South African Airways 2001 (2) SA 1 (CC) par 42 and 45. See further Okpaluba "Extraordinary Remedies for Breach of Fundamental Rights: Recent Developments" 2002 17(1) SAPR/PL 98 111-117.

71 Similar considerations apply to constitutional damages: President of the Republic of South Africa v Modderklip Boerdery (Pty) Ltd 2005 (5) SA 3 (CC) par 65.

72 Seepersad v Attorney General supra par 34.

73 [1984] 1 WLR 522530.

74 Attorney General v McLeod supra 531.

75 Reference to the 1962 Constitution of Trinidad and Tobago then in operation, see now s 4(a) of the 1976 Constitution of the Republic of Trinidad and Tobago.

76 Maharaj v Attorney General of Trinidad and Tobago (2) supra 399-400. 
exceptional. In other words, the circumstances must be exceedingly extraordinary for such a relief to be granted by a court. Although, in its wake, Maharaj (2) has left thoroughly disappointed those who might have conceived it as having flung open the floodgates of constitutional redress litigation, subsequent decisions have shown that the ingredients contained therein enable the courts to apply its principle within judicially controllable limits.

Lord Diplock took time in his formulation to factor-in elements that would prevent the application of the principle to circumstances that would tantamount to abuse of process. He offered an explanation that even where a judge has failed to observe one of the fundamental rules of natural justice, it does not bring the case within section $6^{77}$ unless it has resulted, is resulting or is likely to result, in a person being deprived of life, liberty, security of the person or enjoyment of property. Indeed, he said:

"It is only in the case of imprisonment or corporal punishment already undergone before an appeal can be heard that the consequences of the judgment or order cannot be put right on appeal to an appellate court. It is true that instead of, or even as well as, pursuing the ordinary course of appealing directly to the appellate court, a party to legal proceedings who alleges that a fundamental rule of natural justice has been infringed in the course of the determination of his case, could in theory seek collateral relief in an application to the High Court under section 6(1) with a further right of appeal to the Court of Appeal under section 6(4). The High Court, however, has ample powers, both inherent and under section 6(2), to prevent its process being misused in this way ..."

The foregoing qualifications obviously provide the narrow confines within which the constitutional motion could successfully proceed. However, the question with which the courts in the Caribbean have been confronted since the last three decades is: what claims can be brought to court through the constitutional motion? At first blush, this question may appear simple but it has not at any point elicited a straightforward answer. For instance, in Suratt $v$ Attorney General (2) ${ }^{79}$ the appellant sought to recover damages for the nonimplementation of an Act of Parliament simply because the Privy Council had previously held that the impugned Equal Opportunity Act 2000 Act was not unconstitutional but that it be implemented "without further delay". ${ }^{80}$ Lord Brown held that, whether or not, the non-implementation of the Act was to be regarded properly as having deprived the appellants of the protection of the law, the making of the declarations in the earlier case by their Lordships provided the appellants with proper and "sufficient redress" pursuant to section 14 of the Constitution. ${ }^{81}$ By analogy, the House of Lords held in $R$ (Greenfield) $v$ Secretary of State for the Home Department ${ }^{82}$ that the court should award damages only where it is satisfied that loss had in fact been caused by the violation. Like in this case, the judgment of unconstitutionality is just satisfaction for breach of any right of the appellants. Similarly, the facts of and the constitutional rights implicated in Suratt, were no equivalent to those

See now s 14 of the Constitution of the Republic of Trinidad and Tobago, 1976.

78 Maharaj v Attorney General of Trinidad and Tobago (2) supra 399-400.

79 [2008] UKPC 38 (PC).

80 Suratt $v$ Attorney General of Trinidad and Tobago (1) [2007] UKPC 55 (PC).

81 Suratt $v$ Attorney General (2) supra par 8 and 9.

82 [2005] 1 WLR $673(\mathrm{HL})$. 
in the landmark case of Maharaj (2), nor could they compare with Ramanoop where the police had brutalized a citizen in violation of his constitutional rights and the Privy Council made an additional award to reflect the sense of public outrage, to emphasize the importance of the constitutional right and the gravity of the breach as well as deter further breaches. ${ }^{83}$ Not even a compensatory award was due in Suratt.

Inherent in the language of the constitutional remedies provision of section $14(2)$ is the discretion of the court to grant such a relief in the enforcement of a fundamental right. ${ }^{84}$ In effect, what subsection (1) did not provide for is nonetheless incorporated by judicial construction of section 14(2) of the Constitution. This was the lesson the judgment of Lord Diplock delivered to the plaintiff in Harrikissoon $v$ Attorney General. ${ }^{85}$ The case involved pure administrative-law dispute in which the plaintiff/school-teacher alleged that he was transferred to another school in breach of the principle of natural justice. The plaintiff could ordinarily have applied to the High Court by way of judicial review to have that decision reviewed. Instead, he applied to the High Court under section 6(1) of the Constitution ostensibly to enforce his fundamental right. Lord Diplock made it clear that it was not every failure by an organ of Government or a public authority or public officer to comply with the law that necessarily entails the contravention of some human right of the individual within the contemplation of Chapter I of the Constitution. He held that the right to apply under section 6 for redress upon a breach of a fundamental right was "an important safeguard of those rights and freedoms" such that the value of the right to constitutional redress "will be diminished if it is allowed to be misused as a general substitute for the normal procedures for invoking judicial control of administrative action". Further, a constitutional claim would not be allowed if it was "an abuse of the process of the court as being made solely for the purpose of avoiding the necessity of applying in the normal way for the appropriate judicial remedy for unlawful administrative action which involves no contravention of any human right or fundamental freedom". ${ }^{86}$

Lord Diplock reiterated the same warning against the misuse of constitutional motion in Chokolingo v Attorney General. ${ }^{87}$ The appellant had sought to use the section 6 redress procedure as a means of collateral attack upon the judgment of court acting within jurisdiction. Chokolingo, editor of a newspaper, was convicted of contempt for "scandalising the court" and committed to prison for 12 days. By a constitutional motion brought two years after his conviction he contended that "scandalising the court" no longer amounted to a criminal contempt in Trinidad and Tobago. He relied on his right to due process under section 4(a). For the Privy Council, Lord Diplock held:

"It was argued on behalf of the applicant that, if he could persuade the Board that, because it had become obsolete long before 1962, no such offence as 'scandalising the court' was known to the common law in force in Trinidad at the commencement of the Constitution, this would entitle the applicant to

33 Attorney General v Ramanoop supra par 19.

84 Attorney General v Ramanoop supra par 23.

85 Supra.

86 Harrikissoon v Attorney General supra 268.

87 [1981] 1 WLR 106 (PC) 111-112. 
redress under section 6 [of the 1962 Constitution now section 14 of the 1976 Constitution] for his having been imprisoned by the state for exercising his constitutional rights of freedom of expression and freedom of the press. ... Even if it were possible to persuade their Lordships that [this] publication ... no longer constituted a criminal contempt of court ..., it would merely show that the judge had made an error of substantive law as to a necessary ingredient of the genus of common law offences which constitute contempt of court. In their Lordships' view there is no difference in principle between this kind of error and a misrepresentation by a judge, in the course of an ordinary criminal trial, of the words of the Act of Parliament creating the offence with which the accused is charged. If the former is open to collateral attack by application to the High Court under section [14] of the Constitution so must the latter be."

Similar warning was repeated in Attorney General v McLeod, ${ }^{89}$ where the invalidity of an Amendment Act was questioned. It was reiterated by Lord Bingham in Hinds $v$ Attorney General of Barbados. ${ }^{90}$ Unlike in Harrikissoon and Chokolingo, where no fundamental rights existed or breached, the plaintiff in Jaroo was able to show that his constitutional rights were implicated and that they were indeed infringed. That notwithstanding, their Lordships were uncompromising on the use of the constitutional process as they held that the plaintiff was not entitled to the declaration sought because it was an abuse of process for him to have proceeded by way of a constitutional motion. It was held further that, where there was an alternative remedy, the right to apply to the High Court under section 14(1) of the Constitution, was to be exercised only in exceptional circumstances. The originating motion procedure under that sub-section was appropriate for use in cases where the facts were not in dispute and questions of law only were at issue. ${ }^{91}$ The appropriateness of the procedure afforded by section 14(1) had to be capable of being tested at the outset, when a person applied by way of an originating motion to the High Court. $^{92}$ All the court had at that stage before it was the allegation and the answer to the question whether or not that allegation could be established lay in the future. Disputes of this kind had to be resolved by using the procedures available in the ordinary courts at common law. Adopting the opinion of Lord Mustill in Boodram v Attorney General, ${ }^{93}$ Lord Hope held in Jaroo that:

"the question whether the appellant's complaint that the police were detaining his vehicle was well founded was a matter for decision and, if necessary, remedy the use of the ordinary and well-established procedures which exist independently of the Constitution. But, instead of amending his pleadings to enable him to pursue the common law remedy that had always been available to him, the appellant chose to adhere to what had now become an unsuitable and inappropriate procedure".

88 Chokolingo v Attorney General supra 111.

89 See fn 73 above. See also Boodram v Attorney General [1996] AC 842854 per Lord Mustill; Ahnee v Director of Public Prosecutions [1999] 2 AC 294 (PC) 307; and Observer Publications Ltd v Matthew (2001) 58 WIR 188206 (PC).

90 [2002] 2 WLR 470484.

91 Jaroo v Attorney General [2002] 5 LRC 258 (PC) par 36.

92 Jaroo v Attorney General supra par 39.

93 [1996] 2 LRC 196 (PC) 205-206.

94 Jaroo v Attorney General supra par 36. Jaroo was distinguished in Bhagwandeen $v$ Attorney General [2004] UKPC 21 par 17 on the ground that the appellant had a sufficient claim in detinue whereas the present case could be said to constitute a bona fide resort to rights under the Constitution which ought not to be discouraged. See also per Lord Steyn in Ahnee $v$ Director of Public Prosecutions supra (307), where their Lordships were willing, without 
In accordance with the foregoing principle, Lord Hope held in Seepersad that the issues the appellants raised were of a constitutional nature. ${ }^{95}$ Accordingly, the argument that the sentences themselves offended against the constitutional principle of separation of powers was certainly of that character. At least that provided the necessary grounds for a conclusion that an application for constitutional relief was the appropriate remedy. ${ }^{96}$ Again, no objection was raised in the parallel case of Chuck Attin $v$ Attorney General, ${ }^{97}$ to the effect that a remedy was sought by way of a constitutional motion in that case. Neither was objection taken to the present proceedings in the courts below on the ground that they were an abuse of process because the alternative remedy of judicial review was available. The argument before their Lordships that the common law entitled the appellants to a remedy could have been presented by way of an application for judicial review might be true, but this case is quite unlike Jaroo, where the appellant was seeking a declaration that he was entitled to the return of a motor vehicle. Having regard to the history of the proceedings in Seepersad, Lord Hope held that it could not reasonably be said that the court's constitutional jurisdiction was being invoked for the purpose of avoiding the need to apply for judicial review in the normal way. Such an argument must therefore be rejected. ${ }^{98}$ In light of these reasons, it was held that the Court of Appeal erred in law in finding that section 6(1)(a) of the Constitution precluded the appellants from challenging the manner of the execution of their detention on the ground that the failure to review the sentence and detention resulted in a breach of their rights under sections $4(\mathrm{a})$ and (b) and $5(2)(\mathrm{h})$. The appellants were accordingly entitled to a declaration that their constitutional rights were breached by the failure to conduct such reviews. ${ }^{99}$

\section{Is there a constitutional right to damages?}

Affirming the discretionary nature of the section 14 relief, ${ }^{100}$ and reiterating that the rights protected by section 4 were not absolute, at least in most instances, ${ }^{101}$ Lord Hope held in Seepersad that "[t]here is no constitutional right to damages". ${ }^{12}$ For, in some cases, a declaration of a violation of the constitutional right may be sufficient satisfaction for what has happened. ${ }^{103}$ In others, it will be enough for the court to make a mandatory order of the kind that was made in this case, when the trial judge ordered that the terms of the

deciding the point, to proceed on the assumption that the appellant was entitled to advance his claim for damages by way of the constitutional motion.

95 Contra in Brent Griffith v Revenue Authority of Guyana [2006] CCJ 2 (AJ); Yasseen v Attorney General of Guyana [2008] CCJ 3 (AJ); Gibson v Attorney General of Guyana [2008] CCJ 8 (AJ); and Edwards v Attorney General of Guyana [2008] CCJ 10 (AJ).

96 Seepersad v Attorney General supra par 36.

97 HCA No 2175 of 2003 (unreported).

98 Seepersad v Attorney General supra par 36.

99 Seepersad v Attorney General supra par 37.

100 Per Lord Brown, Suratt $v$ Attorney General (2) supra par 13.

101 Per Lord Bingham, Suratt $v$ Attorney General of Trinidad and Tobago (1) [2008] AC 655 (PC) par 33.

102 Seepersad v Attorney General supra par 38.

103 Inniss v Attorney General of Saint Christopher and Nevis supra par 21; and James v Attorney General supra par 37. 
appellants' detention be determined by the High Court. Thus, to treat entitlement to monetary compensation as automatic where violation of a constitutional right had occurred would undermine the discretion that is invested in the court by section $14 .{ }^{104}$ Coupled with this, each case depends on its own circumstances. ${ }^{105}$

It was held further that in deciding whether damages were appropriate in this case, the following facts must be taken into consideration. First, having been held on remand for five years before their case came to trial, the appellants were denied a review of their detention by a judge for more than 19 years. Second, it was said that their detention was reviewed from time to time under rule 281 of the Prison Rules, which required that the case of every prisoner serving a life sentence be reviewed at four-yearly intervals. Third, their Lordships were shown a fourth-year confidential report on the first appellant dated 21 November 1997 in which it was said that his eighth-year confidential report would become due on 28 July 2001. Fourth, they were also shown a confidential report on the second appellant dated 3 May 1994 in which it was said that his fourth-year report would become due on 28 July 1997. Fifth, while it appeared that the requirements of rule 281 were adhered to, it is equally clear that they fell well short of the kind of review that was regarded in $R \vee$ Secretary of State for the Home Department, Ex parte Venables ${ }^{106}$ and $R$ (Smith) $v$ Secretary of State for the Home Department ${ }^{107}$ as an intrinsic feature of the sentence provided for by section 79 of the Children Act. Six, their Lordships were not shown any report indicating that any consideration was given to the question as to how long it would be appropriate for the appellants to be detained or to their progress and development while they were in custody. Seven, the appellants were given no reason to think that their detention was not to continue indefinitely. Lastly, the possibility that this breach of their constitutional rights had a significant effect on them cannot be entirely ruled out. In these circumstances, there was something to be said for the view that an award of damages might be appropriate. ${ }^{108}$ Having held that the appellants' rights under sections 4(a) and (b) and 5(2)(h) of the Constitution were breached by the failure to review their sentences and detention during the period they were in custody, their Lordships held that they were entitled to damages to be assessed by a judge of the High Court. ${ }^{109}$

\section{MUST A CLAIMANT FOR CHARTER DAMAGES IN CANADA FIRST OBTAIN JUDICIAL REVIEW?}

The Supreme Court of Canada having established ${ }^{110}$ that damages are recoverable as appropriate and just relief under section 24(1) of the Canadian

\footnotetext{
104 Per Lord Kerr, James v Attorney General supra par 36.

105 Seepersad v Attorney General supra par 38.

${ }^{106}$ [1998] AC 407 (HL).

107 [2006] 1 AC $159(\mathrm{HL})$.

108 Seepersad v Attorney General supra par 39.

109 Par 42.

110 Vancouver (City) $v$ Ward [2010] 2 SCR 28 (SCC).
} 
Charter of Rights and Freedoms 1982, ${ }^{111}$ and literally foreclosing the possibility of pursuing that line of attack in the constitutional damages litigation, Government lawyers in Canada devised another method of resisting constitutional damages claims. The new approach is to challenge the jurisdiction of the court to hear an action for damages where judicial review had not been obtained by the plaintiff. This is something akin to the raging debate over the use and misuse of the constitutional motion to access constitutional damages in Commonwealth Caribbean constitutional litigation. The difference is that the Canadian cases raise the issue of jurisdiction between the Federal Court and Provincial Courts. Otherwise, the Canadian challenge equally involves access to justice to obtain redress in the nature of damages where a Charter right is implicated. Another point of departure is that the Canadian courts do not maintain the rigid distinction between tort claims and Charter damages as has been the approach of Maharaj (2) and subsequent Caribbean cases.

\section{Laying down the ground rules}

The Supreme Court of Canada was inundated with six cases raising similar issues of the jurisdiction of the Federal Court to hear Charter-damages claims without the applicant having approached the Provincial Court for judicial review. All six cases were decided the same day, 23 December 2010. The court took the opportunity of the first case, Canada (Attorney General) $v$ TeleZone Inc, ${ }^{112}$ a civil-law action, to provide a comprehensive judgment which became the model for the other five judgments. TeleZone (TZ) filed an action for damages against the Federal Crown in Ontario Superior Court of Justice for breach of contract, negligence and unjust enrichment arising from a ministerial decision rejecting its application for a telecommunications licence. Relying on Canada $v$ Grenier, ${ }^{113}$ the Attorney General of Canada challenged the jurisdiction of the Superior Court on the ground that the claim constituted a collateral attack on the decision. This was barred by section 18 of the Federal Courts Act which grants the Federal Court exclusive judicial review jurisdiction in relation to decisions of all federal boards, commissions or other tribunals. By the Grenier principle, the Crown was shielded from private law damages involving any of its agencies or entities in respect of losses caused by unlawful decision-making without first passing through the Federal Court. On a preliminary motion, the Attorney General urged the Superior Court to dismiss the action for want of jurisdiction because TZ must first have the Minister's order quashed on judicial review in the Federal Court as a condition precedent to a civil suit against the Crown. The Superior Court dismissed the objection on the ground that it was not plain and obvious that the claim would fail. ${ }^{114}$ The Court of Appeal upheld that decision, holding that Grenier had not been correctly decided because section 17 of the Federal Courts Act and section 21 of the Crown Liability and Proceedings Act 1985

\footnotetext{
111 S 24(1) of the Charter provides that: "Anyone whose rights or freedoms, as guaranteed by this Charter, have been infringed or denied may apply to a court of competent jurisdiction to obtain such remedy as the court considers appropriate and just in the circumstances."

112 Canada (Attorney General) v TeleZone Inc supra.

113 [2006] 2 FCR 287.

114 Canada (Attorney General) v TeleZone Inc (2007) 88 OR (3d) 173.
} 
conferred concurrent jurisdiction on the superior courts and the Federal Court for claims against the Crown. Section 18 of the Federal Courts Act did not remove relief by way of an award of damages from the jurisdiction of superior courts. ${ }^{115}$

For the Supreme Court, Binnie $\mathrm{J}$ held that the appeal was fundamentally about access to justice. People who claimed to be injured by Government action should have access to whatever redresses the legal system permitted through procedures that minimize unnecessary costs and complexity. The court's approach should be practical and pragmatic with that objective in mind. ${ }^{116}$ If a claimant sought to set aside the order of a federal decisionmaker, he/she would have to proceed by judicial review, as the Grenier court held. However, if the claimant was content to let the order stand and instead sought compensation for alleged losses as the plaintiff had done in that case, there was no principled reason why it should have been forced to detour to the Federal Court for the extra step of the sometimes costly judicial review application when that was not the relief it sought. Access to justice required that the claimant be permitted to pursue his/her chosen remedy directly and, to the greatest extent possible, without procedural detours. ${ }^{17}$ Acceptance of Grenier would undermine the effectiveness of the Federal Courts Act reforms of the early 1990s by retaining in the Federal Court exclusive jurisdiction over a key element of many causes of action proceeding in the provincial courts despite Parliament's promise to give plaintiffs a choice of forum and to make provincial superior courts available to litigants "in all cases in which relief is claimed against the [federal] Crown"118 except as otherwise provided. ${ }^{119}$

Again, the Federal Courts Act contains other internal evidence that Parliament could not have intended judicial review to have the gatekeeper function envisaged by Canada $v$ Grenier. ${ }^{120}$ Section 18.1(2) imposes a 30-day limitation for judicial review applications. A 30-day cut-off for a damages claimant would be unrealistic, as the facts necessary to ground a civil cause of action may not emerge until after 30 days have passed, and the claimant may not be in a position to apply for judicial review within the limitation period. ${ }^{121}$ While the 30-day limit can be extended, the extension is discretionary and would subordinate the fate of a civil suit brought in a superior court to the discretion of a Federal Court judge ruling upon a request for an extension of time for reasons that have to do with public-law concerns, not civil damages. ${ }^{122}$ Moreover, the grant of judicial review is itself discretionary and may be denied even if the applicant establishes valid grounds for the court's intervention. ${ }^{123}$ This does not align well with the paradigm of a common law action for damages where, if the elements of the

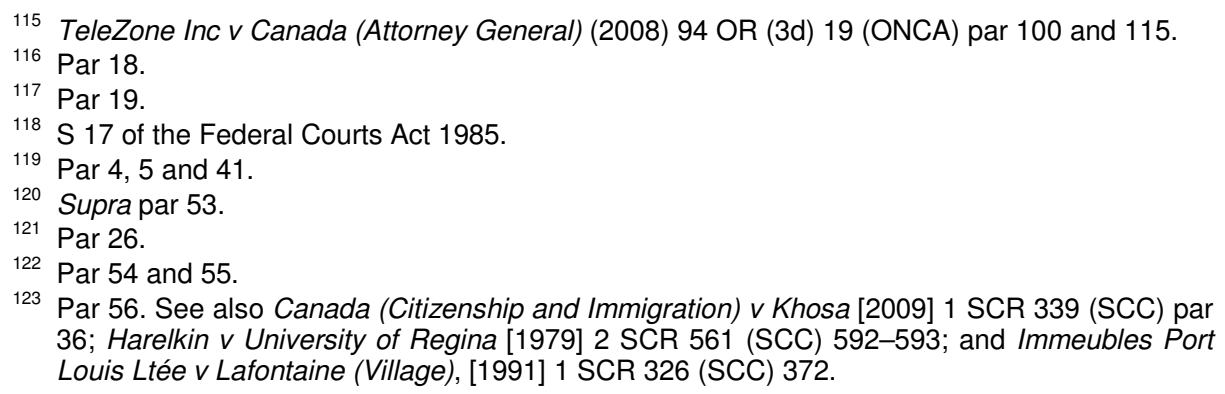


claim are established, compensation ought generally to follow as a matter of course. ${ }^{124}$ Further, section 8 of the Crown Liability and Proceedings Act 1985, which codifies the defence of statutory authority, is evidence that Parliament envisaged that the lawfulness of administrative decisions could be assessed by the provincial superior court in the course of adjudicating a claim for damages.

The Grenier approach cannot be justified by the rule against collateral attacks. TZ's claim was not an attempt to invalidate or render inoperative the Minister's decision; rather, the decision and the financial losses allegedly consequent to it constitute the very foundation of the damages claim. ${ }^{126}$ In any event, given the statutory grant of concurrent jurisdiction in section 17 of the Federal Courts Act, Parliament has stated that provincial superior courts possess concurrent jurisdiction necessary to dispose of the whole of a claim and this includes any attack on the validity of the Minister's decision where this issue is essential to the cause of action and where adjudicating the matter is a necessary step in disposing of the claim. ${ }^{127}$ While the doctrine of collateral attack may be raised by the Crown in the provincial superior court as a defence, the possible availability of the defence is not an argument against provincial superior court jurisdiction. ${ }^{128}$ Similarly, while it may be open to the Crown, by way of defence, to argue that the Government decision-maker was acting under statutory authority which precludes compensation for consequent losses, this is not a matter of jurisdiction and can be dealt with as well by the provincial superior court as by the Federal Court. ${ }^{129}$ TZ's claim as pleaded was dominated by private-law considerations. ${ }^{130}$ It did not attempt to nullify or set aside the decision to issue licences. Nor did it seek to deprive the decision of any legal effect. TZ's causes of action in contract, tort and equity were predicated on the finality of that decision excluding it from participation in the telecommunications market, thereby causing it financial loss. ${ }^{131}$ The Ontario Superior Court of Justice therefore has jurisdiction over the parties and the subject matter, and has the power to grant the remedy of damages. There is nothing in the Federal Courts Act to prevent the Ontario Superior Court from adjudicating TZ's claim. ${ }^{132}$

\section{Applying the model to McArthur's case}

In Canada (Attorney General) $v$ McArthur, ${ }^{133} \mathrm{M}$ spent approximately four years and six months in solitary confinement, segregation or in a special handling unit on instructions of $B$ or other federal employees for whom the Crown was responsible. He did not seek to set aside the prison orders, but

\footnotetext{
${ }^{124}$ See Brown and Evans Judicial Review of Administrative Action in Canada (1998 loose-leaf updated July 2010) par 3:1 100.

125 TeleZone Inc $v$ Canada (Attorney General) supra par 46.

${ }^{126}$ Par 64.

${ }_{127}$ Par 67.

128 Par 72.

129 Par 69.

130 Par 80.

${ }^{131}$ Par 79.

132 Par 81.

133 Supra.
} 
some years later, filed a statement of claim in the Ontario Superior Court seeking damages and alleging that his detention had been arbitrary and constituted cruel and unusual punishment, contrary to sections 9 and 12 of the Canadian Charter of Rights and Freedoms 1982. He claimed to have suffered severe emotional and psychological injury and harm. He also alleged that the decisions to place him in solitary confinement were made deliberately and maliciously or negligently. The Superior Court ${ }^{134}$ dismissed the claim on the basis of Canada $v$ Grenier, ${ }^{135}$ but the Court of Appeal overturned the decision on the ground that relief by way of damages was available in the superior court. ${ }^{136}$

For the same reasons set out in TeleZone, ${ }^{137}$ Binnie $\mathrm{J}$ held that the provincial superior court had jurisdiction to hear the plaintiff's claim for compensation both in its constitutional aspect under section 24(1) of the Charter ${ }^{138}$ as well as in tort because its authority extends to "the person and the subject matter in question and, in addition, [because it] has authority to make the order sought". ${ }^{139}$ Otherwise, "a textual, contextual and purposive interpretation of the Federal Courts Act" ${ }^{\prime 140}$ does not support the view that a plaintiff who claims to have suffered compensable loss as a result of an administrative decision had to first have the lawfulness of the decision determined by the Federal Court. Further, the Federal Courts Act does not prevent provincial superior court scrutiny of the constitutionality of the conduct of federal officials. ${ }^{141}$ Here, the Superior Court is authorized to consider the validity of M's detention in the context of his damages' claim, as well as the impact, if any, of any valid detention orders on Crown liability. ${ }^{142}$ The collateral attack doctrine does not support the Attorney General's jurisdictional challenge in light of the explicit statutory grant of jurisdiction to the provincial superior courts in respect of claims against the Crown in section 17 of the Federal Courts Act and section 21 of the Crown Liability and Proceedings Act $1985 .^{143}$ There was nothing in the Federal Courts Act to give the Federal

\footnotetext{
${ }^{134} 2006$ CarswellOnt 9820.

135 Supra.

136 (2008) 94 OR (3d) 19.

137 TeleZone Inc v Canada (Attorney General) supra. See also: Parrish \& Heimbecker Ltd v Canada (Agriculture and Agri-Food) [2010] 3 SCR 639 (SCC) (action brought in Federal Court against the federal Crown for damages for various torts arising from licensing decisions); $\mathrm{Nu}$ Pharm Inc v Canada (Attorney General) [2010] 3 SCR 645 (SCC) (action in Federal Court against the federal Crown for damages for various torts arising from decisions prohibiting sale of drugs); Canadian Food Inspection Agency v Professional Institute of the Public Service of Canada [2010] 3 SCR 657 (SCC) (action brought against Crown servants and union in Superior Court of Quebec alleging civil liability, defendants bringing recources in warranty against federal agency); and Manuge v Canada [2010] 3 SCR 672 (SCC) (action brought by plaintiff in Federal Court against the federal Crown for constitutional remedies, declaratory relief and damages arising from establishment, modification and application of long-term disability benefits plan).

${ }^{138}$ Canada (Attorney General) v McArthur supra par 14

139 Par 17, citing per Mclntyre J Mills v The Queen [1986] 1 SCR 863 (SCC) 960 who quoted per Brooke JA in R v Morgentaler (1984) 41 CR (3d) 262 (SCC) 271, and per Lamer J (as he then was) 890. See also, $R$ v Rahey [1987] 1 SCR 588 (SCC) 603; $R$ v 974649 Ontario Inc. [2001] 3 SCR 575 (SCC) par 15; and $R v$ Conway [2010] 1 SCR 765 (SCC).

140 Canada (Attorney General) v McArthur supra par 12.

141 Par 14

142 Par 15.

143 Par 16.
} 
Court the exclusive jurisdiction to determine the lawfulness or validity of the order of a federal board, commission or other tribunal. To hold otherwise would undermine an explicit statutory grant of jurisdiction to the superior courts of the provinces and would be for formalistic reasons that are neither compelling nor consistent with the promotion of access to justice in a direct and cost-efficient manner. ${ }^{144}$

\section{CONCLUSION}

The judgment in Seepersad has established that there is neither a right to constitutional remedy nor a constitutional right to damages. And whether a constitutional relief or constitutional damages were appropriate in any case depends on the circumstances. For instance, where no alternative judicial redress exists and the constitutional wrong is in the past, not only that a constitutional relief would be called for, but also constitutional damages may be more fitting than any other judicial remedy. Again, in a situation such as the appellants found themselves in Seepersad, where the legal system failed to provide them the basis for judicial review or the appeal structure, it was unrealistic to expect an applicant for constitutional redress to have availed himself of non-existent alternative judicial remedy. Considering the vital aspects of the Maharaj 2 formulation and given the facts and the nature of the right infringed, Seepersad perfectly qualified for the award of constitutional damages as against those cases where constitutional relief were sought in non-constitutional fact-situations.

Just as the Privy Council judgments in James, Graham and Seepersad have contributed immensely to the constitutional damages jurisprudence in the Caribbean and the Commonwealth, so also, the Canadian Supreme Court has emphatically held that an applicant for section 24(1) Charter damages or public-law damages through the law of tort, is not obliged to take the circuitous and uncertain route of applying for judicial review first and constitutional- or public-law damages later. Indeed, TeleZone and McArthur have prevented a double discretion jeopardy that might befall a party in such circumstances: the risk that he/she might not obtain the remedy of judicial review as well as Charter damages. These judgments have not only restored the right of access to seek constitutional damages in Canadian courts but have also prevented the jeopardy of double expense in the enforcement of Charter rights. 